\title{
Sistem Pendukung Keputusan Pemberian Pembiayaan Murahabah dengan Fuzzy Analytic Hierarchy Process
}

Decision Support System For Murabahah Financing Using Fuzzy Analytic Hierarchy Process

\author{
Siti Monalisa*1, Raynaldi Setiawan ${ }^{2}$ \\ ${ }^{1,2}$ Jurusan Sistem Informasi, UIN Suska Riau, Pekanbaru \\ e-mail: *1 siti.monalisa@uin-suska.ac.id, ${ }^{2}$ setiawanray17@gmail.com
}

\begin{abstract}
Abstrak
BMT Al-ittihad terdapat bermacam-macam pembiayaan salah satunya Murabahah yang berarti akad jual beli barang dengan menyatakan harga perolehan dan keuntungan (margin) yang disepakati oleh penjual dan pembeli. BMT Al-itthad dalam proses melaksanakan akad Murabahah dilakukan dengan menganalisa kelayakan pemberian pembiayaan kepada anggota dengan cara melengkapi persyaratan umum dan menggunakan bahasa yang subjektif terhadap penilaian kriteria karakter berdasarkan rekomendasi anggota lain,wawancara dan cara berkomunikasi, Penilaian karakter merupakan penilaian yang paling penting berdasarkan hasil wawancara dengan kepala pembiayaan karena penilaian karakter merupakan penilaian untuk melihat apakah anggota sanggup dan amanah membayar hutang. Untuk mengatasi penilaian yang bersifat subjektif maka dirancang sebuah sistem pendukung keputusan pemberian pembiayaan dengan menggunakan metode fuzzy analytic hierarchy process. Metode fuzzy AHP merupakan penggabungan dari metode fuzzy dan AHP. Metode fuzzy AHP dapat menutupi kelemahan yang terdapat pada AHP yaitu menangani penilaian yang bersifat subjektif. Sistem ini dirancang menggunakan bahasa pemrograman PHP, MySQL, sedangkan metode pengembangan sistem menggunakan V-model dan UML sebagai standar pemodelannya. Sistem pendukung keputusan ini dapat memudahkan serta mempercepat proses penentuan pemberian pembiayaan Murabahah kepada anggota.
\end{abstract}

Kata kunci-BMT Al Ittihad, fuzzy AHP, Murabahah, Subjektif, V-model

\begin{abstract}
BMT Al-ittihad that there are various financing one of them Murabahah which means contract sale and purchase with profit and profit (margin) agreed by the seller and buyer. BMT Al-itthad in the process of implementing Murabaha Agreement is conducted by analyzing the feasibility in general ways by using general terms and using language appropriate to the characteristics of others, interviews and consultation, and is the only thing that matters. an interview with the head of finance for the content to see if the member is willing and willing to pay the debt. To overcome the existing problems then designed a system that supports the decision by using the method of fuzzy analytic hierarchy process. The AHP fuzzy method is an amalgamation of the fuzzy and AHP methods. Meotde fuzzy AHP can be used on AHP that is subjective statistical handling. This system uses PHP programming language, MySQL, while system development method using V-model and UML as modeling standard. System decision making can provide convenience and extension of process for Murabahah financing to Member
\end{abstract}

Keywords-BMT Al-iitihad, Fuzzy AHP, Murabahah, Subjective,V-model.

\section{PENDAHULUAN}

BMT Al-Ittihad merupakan sebuah lembaga yang bergerak dibidang pembiayaan murahabah yaitu pembiayaan yang berbentuk jual beli antara bank dan anggota dengan 
pembayarannya bersifat angsuran [1]. Berdasarkan wawancara dengan Kepala Bagian Pembiayaan, proses melaksanakan akad Murabahah melakukan analisa kelayakan pemberian pembiayaan kepada anggota dengan cara melihat kelengkapan persyaratan umum dan melakukan penilaian kriteria karakter berdasarkan rekomendasi anggota lain, melakukan wawancara dengan anggota dan menilai cara berkomunikasi. Penilaian karakter merupakan penilaian yang paling penting berdasarkan hasil wawancara dengan kepala pembiayaan karena penilaian karakter merupakan penilaian untuk melihat apakah anggota sanggup dan amanah membayar hutang. Dengan analisa yang digunakan saat ini, terjadi pembiayaan macet yang disebabkan oleh karakter anggota yang tidak baik, karena salah dalam memberikan pembiayaan. Selain itu, proses penentuan layak atau tidaknya mendapatkan dana pembiayaan masih dilakukan dengan cara manual dengan cara para anggota yang mengajukan pembiayaan harus mengisi form pendaftaran yang telah disediakan dalam bentuk kertas beserta kelengkapan persyaratan yang diminta. Kemudian pihak account officer mengambil kelengkapan persyaratan atau proposal serta melakukan survey. Selanjutnya account officer melakukan analisa kelayakan berdasarkan data yang telah diperoleh. Setelah itu proposal yang telah dianalisa dan layak diberikan pembiayaan dimintakan persetujuan kepada kepala pembiayaan kemudian dilanjutkan ke manajer. Waktu yang digunakan untuk proses penerimaan atau penolakan pembiayaan berkisar antara 2-14 hari kerja dengan pembagian waktu yaitu Account officer 2-3 hari kerja dan kepala bagian pembiayaan 2-3 hari kerja serta manajer 2-3 hari kerja. Berkas yang telah disetujui diinputkan kembali kedalam Microsoft office excel selanjutnya disimpan dalam bentuk file-file yang diberi nama sesuai dengan nama peminjam.

Permasalahan yang timbul dari sistem manual pada BMT Al-Ittihad adalah banyaknya waktu yang dibutuhkan untuk menentukan penilaian dan analisa pembiayaan kepada anggota. Selain itu sistem manual juga tidak bisa menentukan penilaian secara otomatis ketika data analisa pembiayaan diinputkan sehingga memperlambat dalam pengambilan keputusan yang dilakukan oleh bagian kepala pembiayaan dan account officer. Oleh karena itu, untuk mempercepat pengambilan keputusan maka diperlukan sistem yang disebut sebagai sistem pendukung keputusan. Sistem Pendukung Keputusan adalah suatu pendekatan untuk mendukung keputusan menggunakan komputer [2] bagi pembuat keputusan manajemen yang menghadapai masalah semi terstruktur [3]. Namun keputusan tersebut tersebut tergantung pada pengambil kebijakan, bukan pada alat atau sistem tersebut [4]. Sistem pendukung keputusan telah banyak digunakan dalam menentukan pemilihan seperti pada kasus penentuan mustahik [5] menggunakan metode fuzzy AHP dengan jumlah kriteria sebanyak 4, pemberian beasiswa dengan metode fuzzy logic tsukamoto dengan jumlah kriteria 4 [6], pemberian bantuan dana atau kredit untuk usaha kecil menengah (UKM) dengan metode simple additive weighting dengan jumlah kriteria 5 [7], prioritas pendirian BTS menggunakan metode fuzzy AHP dengan 6 kriteria [8]. Dari berbagai penelitian mengenai sistem pendukung keputusan menggunakan metode Fuzzy AHP sedikit sekali yang membahas pemberian pembiayaan. Metode fuzzy AHP mampu menghasilkan ketidakpastian penilaian subjektif pada data kualitatif [9] dibandingkan metode keputusan lainnya. Metode fuzzy AHP merupakan penggabungan dari metode fuzzy dan AHP. Metode fuzzy AHP dapat menutupi kelemahan yang terdapat pada AHP yaitu menangani penilaian yang bersifat subjektif yaitu proses wawancara yang dilakukan oleh BMT Al-Ittihad, sehingga dengan menggunakan metode ini, BMT Al-Ittihad mampu memberikan penilaian lebih objektif.

\section{METODE PENELITIAN}

Penelitian ini menggunakan V-Model [10] dengan tahap pengembangan sistem yang dilakukan yaitu user requirements, system requirements, global design, detailed design dan implementaton.

\section{1. $\quad$ User Requirements}

Tahapan ini merupakan tahapan pertama yang dilakukan dengan menggambarkan kebutuhan/harapan pengguna terhadap sistem yang akan dikembangkan. 


\section{System Requirements}

Pada tahap ini, kegiatan yang dilakukan yaitu menguraikan keadaan dan situasi yang ada pada objek penelitian sehingga menjadi sebuah informasi yang dapat diinterprestasikan. Tahap system requirements dikenal juga sebagai tahap mendefinisikan rencana aplikasi. Adapun tahap-tahapannya sebagai berikut:

- Melakukan identifikasi masalah yang terjadi pada sistem yang sedang berjalan pada saat ini.

- Analisa kebutuhan data yang diperlukan dalam pembuatan sistem pendukung keputusan

\section{Global Design}

- Tahapan-tahapan yang lebih rinci dalam melakukan analisis dapat dilihat pada Bab 4.

Setelah mengetahui definisi aplikasi yang akan dibuat, yang meliputi analisis terhadap sistem, maka tahapan berikutnya adalah melakukan perancangan (design). Perancangan di sini dimaksudkan untuk membuat pemodelan terhadap aplikasi baru yang dapat mewakili sistem yang berjalan saat ini di BMT Al-Ittihad Rumbai, global design terdiri dari:

- Pembuatan Model Fuzzy AHP

Pada SPK pemberian pembiayaan murabahah pada anggota di BMT Al-Ittihad Rumbai menggunakan satu metode yaitu menggunakan metode fuzzy AHP untuk menentukan perangkingan anggota yang layak diberikan pembiayaan. Tahapan penelitian metode fuzzy AHP yang digunakan dalam sistem pendukung keputusan pemberian pembiayaan murabahah yang dibangun ditunjukkan pada Gambar 1.

- Perancangan Sistem

- Perancangan Database

4. $\quad$ Detailed Design

Pada tahap detailed design, dilakukan pembagian design sistem menjadi modul-modul yang lebih kecil. Modul merupakan sebuah atribut tunggal dari perangkat lunak yang berisi instruksi-instruksi yang melakukan suatu fungsi tertentu dan sudah mewakili penyimpanan dan struktur data yang jelas. Untuk memenuhi kebutuhan sistem modulmodul ini akan disatukan kembali. Untuk mempermudah dalam coding sistem maka hal ini harus dilakukan. Selanjutnya dilakukan pembuatan perancangan interface yang meliputi halaman-halaman yang ada di dalam sistem. Pembahasan mengenai detailed design dapat dilihat pada Bab 4.

5. Implementation

Proses implementasi sistem adalah pembuatan modul yang telah dirancang sebelumnya sesuai dengan bahasa pemograman yang digunakan dalam sistem yang akan dibangun. Implementasi system akan dilakukan dengan spesifikasi berikut:

- Operating System : Windows 7

- Memory : : $4 \mathrm{~Gb}$

- Bahasa pemrograman: PHP

- Database : Mysql. 


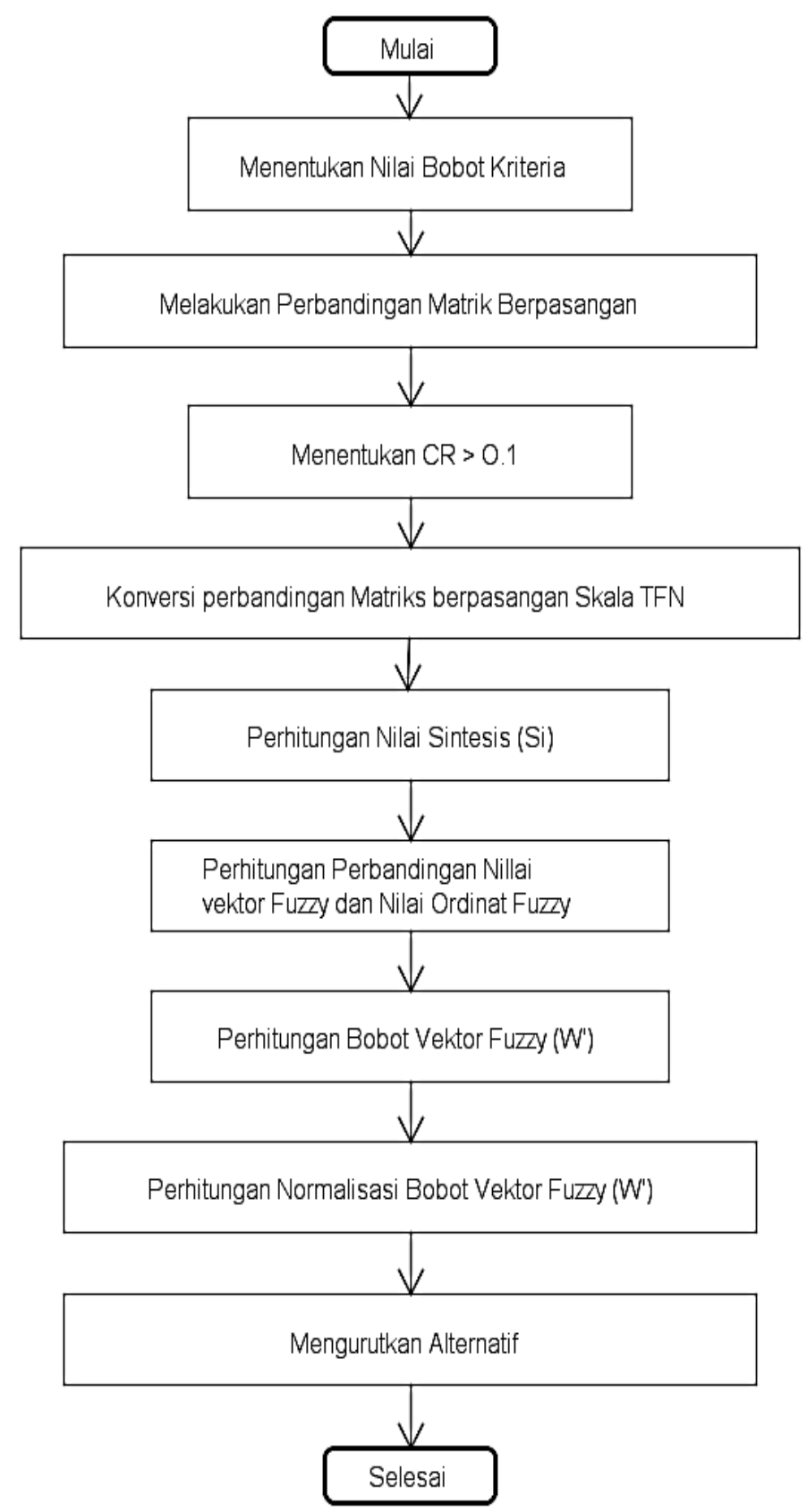

Gambar 1 Tahapan Penelitian dengan Metode Fuzzy AHP

\section{HASIL DAN PEMBAHASAN}

3.1 Analisa sistem yang sedang berjalan

Dalam menentukan anggota pembiayaan murabahah yang tepat untuk dipilih, BMT Alitthad Rumbai melakukan analisa pembiayaan murabahah menggunakan kriteria-kriteria yang telah ditetapkan oleh pihak BMT. Adapun alur dari sistem berjalan dapat dijelaskan sebagai berikut:

1. Anggota pembiayaan mengisi formulir dan melengkapi persyaratan yang telah ditentukan kemudian menyerahkan kepada pihak administrasi. 
2. Pihak Administrasi menerima berkas prososal dan persyaratan pembiayaan dan meneyerahkan kepada bagian Account officer.

3. Account officer menganalisa serta memberikan nilai terhadap proposal anggota pembiayaan sesuai dengan prinsip $5 \mathrm{C}$ (kriteria) yang telah ditentukan.

4. Account officer melakukan survei dan wawancara terhadap anggota yang mengajukan pembiayaan.

5. Account officer menyerahkan proposal yang telah selesai di analisa dan diberikan nilai kepada kepala pembiayaan.

6. Kepala pembiayaan melihat hasil laporan anlisa oleh account officer dan memberikan rekomendasi kepada manajer untuk memilih yang layak diberikan pembiayaan.

7. Manajer memutuskan layak atau tidanya diberikan pembiayaan dan menyerahkan kembali berkas yang telah disetujui kepada account officer.

\subsection{Analisa sistem usulan}

Pada sistem yang diusulkan, dimulai dari menentukan anggota pembiayaan yang layak diberikan pembiayaan murabahah dengan menerapkan metode fuzzy AHP yang dapat di akses oleh account officer, kepala pembiayaan dan manajer, dimana account officer dapat menginputkan data anggota pembiayaan, menginputkan data alternatif, menginputkan data kriteria, mengubah password dan melakukan perhitungan fuzzy AHP. Untuk kepala pembiayaan dapat menambah user sistem, menganti password, memberikan rekomendasi laporan dan melihat data pembiayaan. Sedangkan manajer dapat melakukan ubah password, lihat laporan hasil perhitungan fuzzy AHP, cetak laporan dan melihat data pembiayaan. Sistem pendukung keputusan yang dirancang dapat menerima input (data masukan) anggota pembiayaan, kriteria, alternatif, nilai bobot kriteria, nilai bobot alternatif. Kemudian akan diproses dengan menerapkan perhitungan metode fuzzy AHP yang menghasilkan perangkingan anggota yang layak mendapatkan pembiayaan murabahah.

Perhitungan dengan metode fuzzy AHP dimulai dengan menentukan kriteria penilaian, kriteria tersebut diberi nilai yang telah ditetapkan sebagai acuan, kemudian setiap alternatif diberi nilai kriteria. Setelah itu dilakukan normalisasi matriks berpasangan AHP dilanjutkan mencari nilai konsistensi rasio dimana syarat konsistensi harus kecil dari $10 \%$ atau CR < 0,1. Pada penelitian ini nilai CR nya adalah 0,013.

Selanjutnya konversi matriks berpasangan ke skala TFN dan menghitung nilai sintesis. Setelah di dapat nilai sintesis (ditunjukkan pada Tabel 1) dilanjutkan mencari nilai perbandingan vektor fuzzy dan nilai ordinat. Setelah itu dilakukan penghitungan nilai bobot vektor fuzzy dilanjutkan dengan normalisasi bobot vektor fuzzy sehingga didapatlah hasil perangkingan alternatif mana yang layak mendapatkan pembiayaan. Hasil perangkingan bobot prioritas alternatif pada penelitian ini ditunjukkan pada Tabel 2.

Tabel 1 Penghitungan Jumlah kolom dan Nilai Sintesis Fuzzy AHP (Si) kriteria

\begin{tabular}{|l|l|l|l|l|l|}
\hline & \multicolumn{2}{|l|}{$\sum$ Baris } & & Si & \\
\hline $\mathrm{L}$ & $\mathrm{M}$ & $\mathrm{U}$ & $\mathrm{L}$ & $\mathrm{M}$ & $\mathrm{U}$ \\
\hline 10 & 13 & 16 & 0,10 & 0,18 & 0,296 \\
\hline 10 & 13 & 16 & 0,10 & 0,18 & 0,315 \\
\hline 7,32 & 10,5 & 15 & 0,07 & 0,15 & 0,278 \\
\hline 6,17 & 8,34 & 11,5 & 0,06 & 0,12 & 0,213 \\
\hline 6,17 & 8,34 & 11,5 & 0,06 & 0,12 & 0,213 \\
\hline
\end{tabular}


Tabel 2 Kesimpulan Goal dan Perangkingan Bobot Prioritas Alternatif

\begin{tabular}{|l|l|l|l|l|l|l|l|l|l|}
\hline $\mathbf{K}$ & $\mathbf{W}$ & $\mathbf{C K}$ & $\mathbf{R A}$ & $\mathbf{G A}$ & $\mathbf{J P}$ & $\mathbf{N J}$ & $\mathbf{K J}$ & $\mathbf{K R}$ & $\mathbf{B P}$ \\
\hline B & $\begin{array}{l}0,188797 \\
223\end{array}$ & $\begin{array}{l}0,1887 \\
97223\end{array}$ & $\begin{array}{l}0.15744 \\
922\end{array}$ & $\begin{array}{l}0.11868 \\
6626\end{array}$ & $\begin{array}{l}0.11868 \\
6626\end{array}$ & $\begin{array}{l}0.0893 \\
222\end{array}$ & $\begin{array}{l}0.0893 \\
222\end{array}$ & $\begin{array}{l}0.04883 \\
012\end{array}$ & 1 \\
\hline $\begin{array}{l}\text { A } \\
-1\end{array}$ & 0,2278 & 0,2278 & 0,2278 & 0,2870 & 0,2249 & 0,204 & 0,227 & 0,1054 & 0,2264 \\
\hline $\begin{array}{l}\text { A } \\
-2\end{array}$ & 0,2278 & 0,1054 & 0,1054 & 0,1354 & 0,2249 & 0,204 & 0,105 & 0,2278 & 0,1611 \\
\hline $\begin{array}{l}\text { A } \\
-3\end{array}$ & 0,2278 & 0,2278 & 0,1054 & 0,1354 & 0,1002 & 0,204 & 0,227 & 0,2278 & 0,1803 \\
\hline $\begin{array}{l}\text { A } \\
-4\end{array}$ & 0,1054 & 0,1054 & 0,2278 & 0,0195 & 0 & 0,091 & 0,105 & 0,1054 & 0,1007 \\
\hline $\begin{array}{l}\text { A } \\
-5\end{array}$ & 0,1054 & 0,2278 & 0,2278 & 0,2870 & 0,2249 & 0,091 & 0,227 & 0,1054 & 0,1932 \\
\hline $\begin{array}{l}\text { A } \\
-6\end{array}$ & 0,1054 & 0,1054 & 0,1054 & 0,1354 & 0,2249 & 0,204 & 0,105 & 0,227 & 0,1380 \\
\hline
\end{tabular}

Tabel 2 diatas merupakan kesimpulan goal, tabel ini menjelakan tentang bobot global kriteria yaitu nilai wawancara (W) : 0,188797223, cara berkomunikasi (CB) : 0,188797223, rekomendasi anggota lain (RA) : 0.15744922, gaji anggota (GA) : 0.118686626 , jenis pekerjaan (JP) : 0.118686626, nilai jaminan (NJ) : 0.0893222, kondisi jaminan (KJ) : 0.0893222, kepemilikan rumah (KR) : 0.04883012. Kemudian untuk memperoleh nilai goal dapat dihitung seperti pada baris A-1 atau alternatif dengan nama marzuki (dimisalkan namanya) :

Nilai bobot goal Marzuki

$$
\begin{aligned}
= & (0,227884 * 0,188797223)+(0,227884 * 0,188797223)+(0,227884 * \\
& 0.15744922)+(0,287017 * 0.118686626)+(0,224941 * 0.118686626)+ \\
& (0,204416359 * 0.0893222)+(0,227883845 * 0.0893222)+(0,105449 * \\
& 0.04883012) \\
= & 0.226703
\end{aligned}
$$

Dengan cara yang sama untuk menghitung bobot prioritas A-2, A-3, A-4, A-5 dan A-6. Setelah mendapat nilai total dari setiap alternatif maka langkah berikutnya adalah memilih keputusan dengan nilai tertinggi sebagai nilai alternatif optimal.

Setelah melakukan perhitungan Fuzzy AHP secara manual, tahapan selanjutnya pada penelitian ini adalah membangun perancangan Usecase sistem usulan menggunakan fuzzy AHP untuk pembangunan sistem pendukung keputusan yang ditunjukkan pada Gambar 2. 


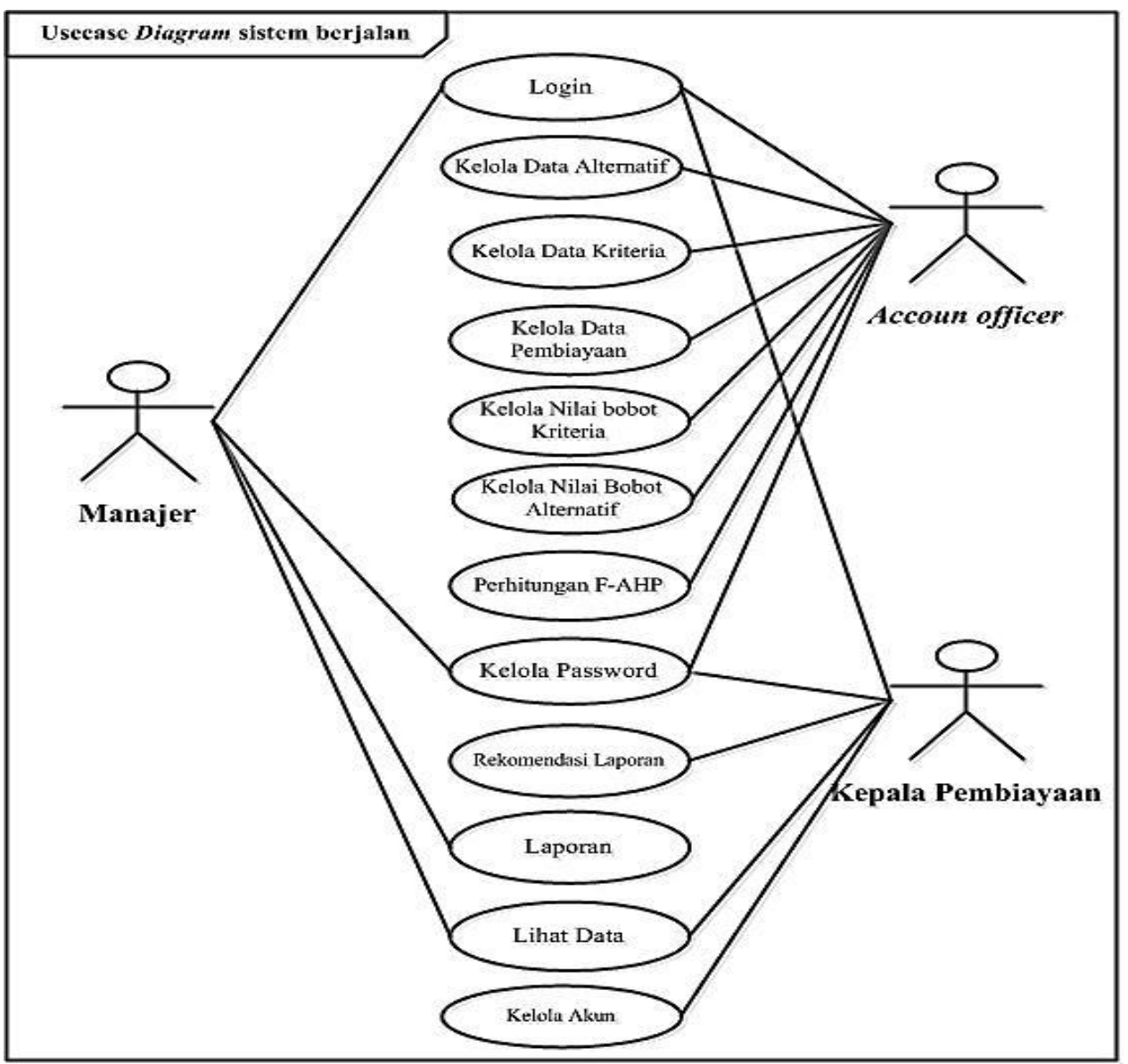

Gambar 2 Usecase Sistem Usulan

\subsection{Implementasi Sistem}

Tahapan berikutnya setelah perancangan adalah implementasi dari perancangan antar muka sistem yang telah dibuat. Dalam sistem pendukung keputusan pemberian pembiayaan murabahah terbagi atas 3 bagian tampilan menu, yaitu:

1. Menu account officer, yang memiliki hak akses memasukkan nilai data anggota pembiayaan, nilai alternatif, nilai kriteria dan melakukan perhitungan fuzzy AHP.

2. Menu kepala pembiayaan, memiliki hak akses mengelola akun atau user yang akan menggunakan sistem dan memberikan rekomendasi kepada manajer siapa yang layak diberikan pembiayaan.

3. Menu manajer, memiliki hak akses untuk melihat hasil perhitungan dan perangkingan fuzzy AHP berupa laporan.

Agar account officer, kepala pembiayaan dan manajer bisa mengakses Sistem Pendukung Keputusan maka pengguna harus memasukkan username dan password. Halaman home account officer merupakan halaman awal dari account officer setelah berhasil melakukan login. Pada halaman home account officer, terdapat 7 (tujuh) menu utama, yaitu home, data master, alternatif, kriteria, nilai bobot, perhitungan dan logout. Home merupakan halaman utama dari sistem, data master merupakan menu yang memiliki sub menu data anggota berfungsi untuk menginputkan nilai anggota pembiayaan, kemudian sub menu kelola password untuk mengatur password baru yang ingin digunakan. Kriteria berfungsi untuk menginputkan nilai ktriteria yang digunakan. Alternatif berfungsi untuk menginputkan nilai alternatif yang akan dihitung. Nilai bobot kriteria merupakan halaman yang digunakan untuk menginputkan nilai yang akan dihitung dan melakukan proses AHP. Nilai bobot alternatif merupakan halaman yang digunakan 
untuk menginputkan nilai alternatif yang akan dihitung dan melakukan proses AHP. Tampilan halaman home account officer ditunjukkan pada Gambar 3.

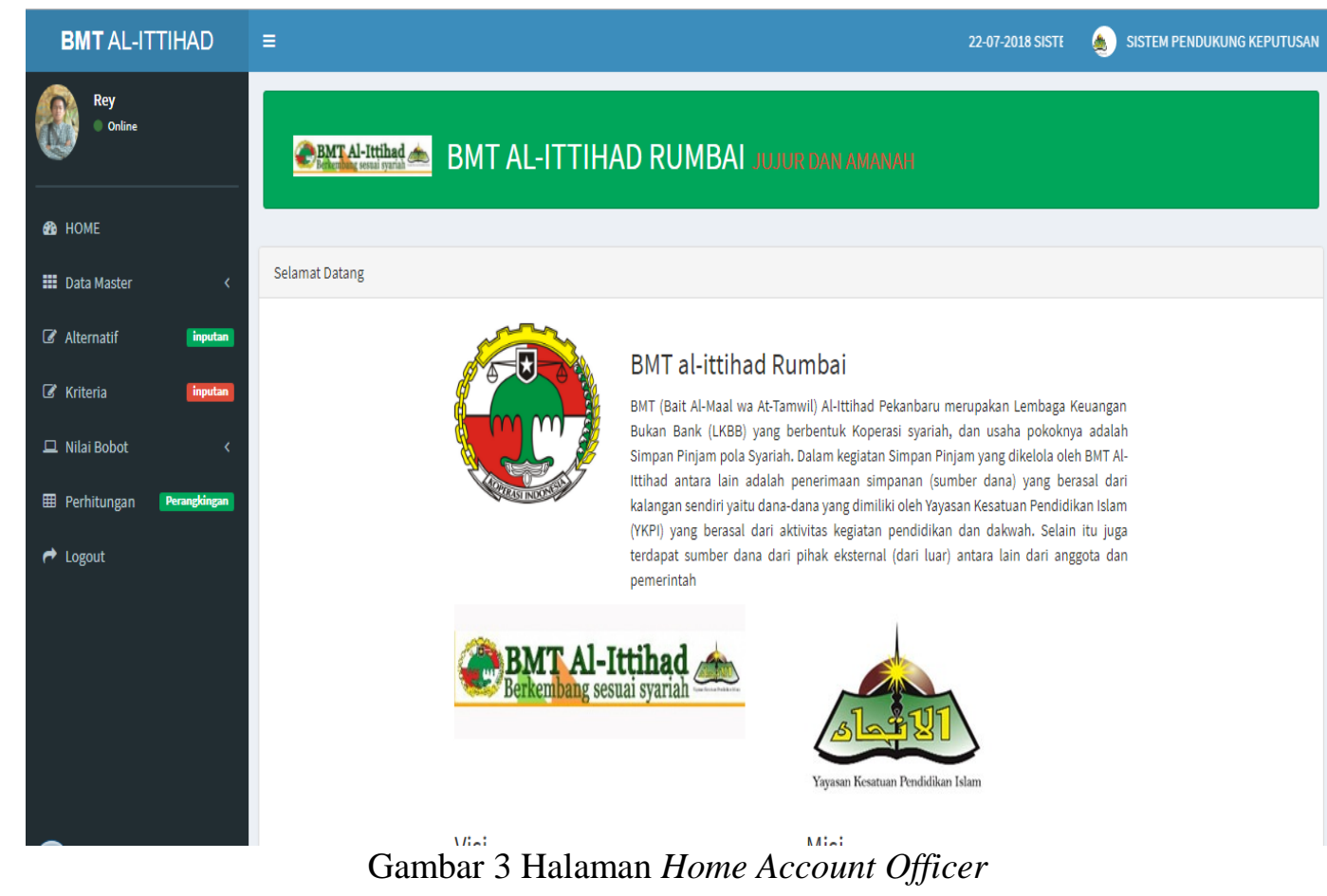

Halaman data pembiayaan merupakan halaman yang diakses oleh Account officer setelah mengklik menu data pembiayaan. Account officer dapat menambahkan data pembiayaan, merubah data pembiayaan dan menghapus data pembiayaan yang telah ada. Tampilan halaman data pembiayaan ditunjukkan pada Gambar 4. Selain itu, Account officer dapat menambahkan data kriteria atau menghapus data kriteria yang telah ada. Tampilan halaman kriteria ditunjukkan pada Gambar 5.

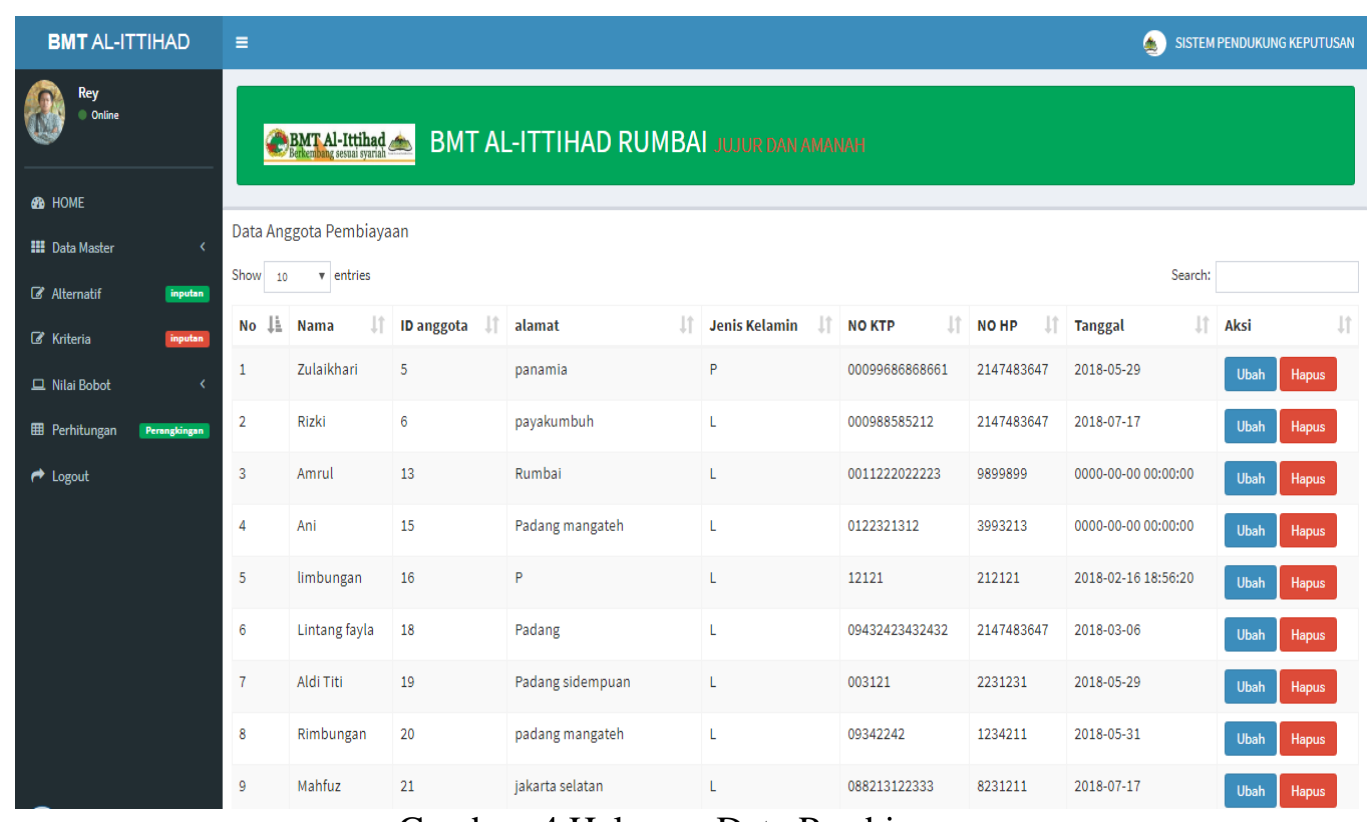

Gambar 4 Halaman Data Pembiayaan 


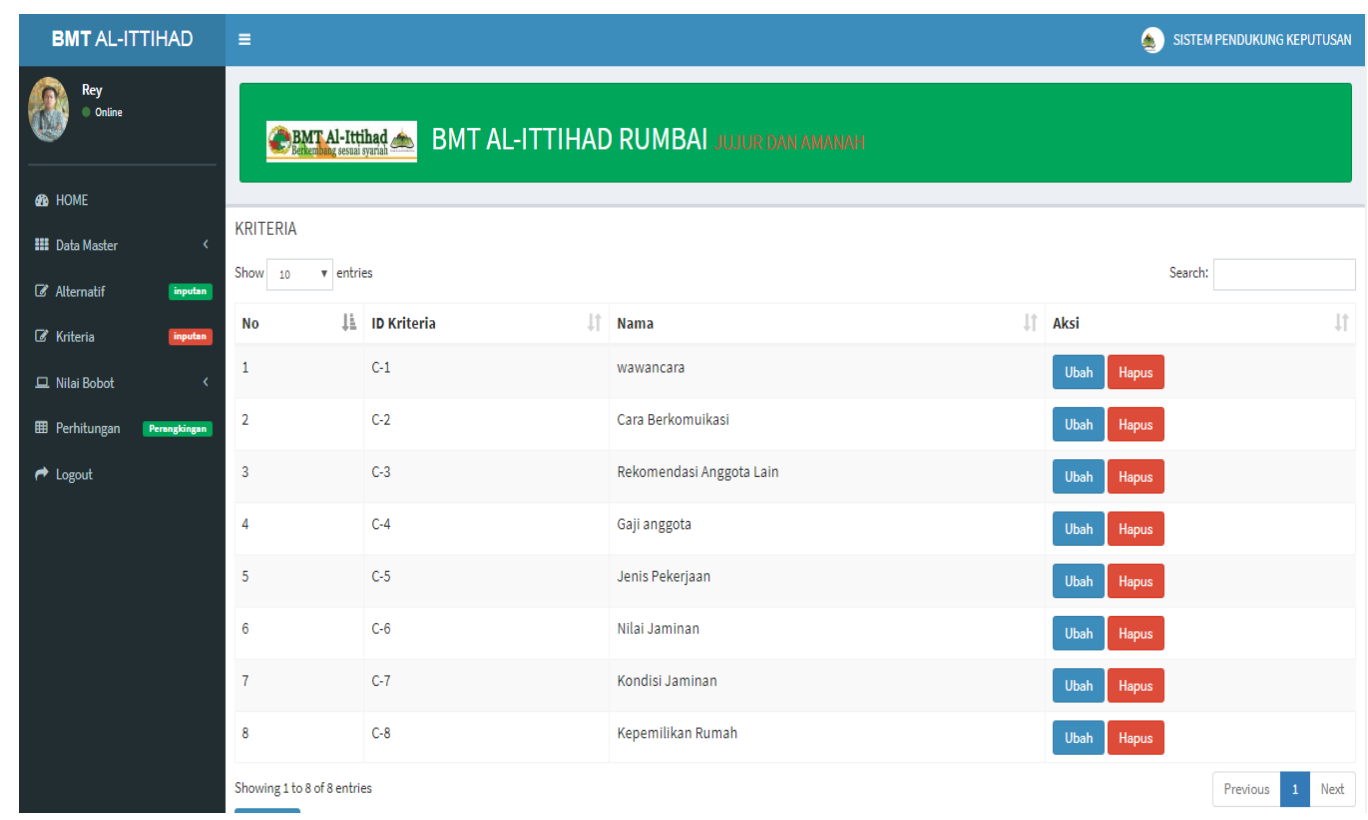

Gambar 5 Halaman Kriteria

Account officer juga dapat menambahkan data alternatif atau menghapus data alternatif yang telah ada. Tampilan halaman alternatif dapat ditunjukkan pada Gambar 6. Account officer dapat menambahkan data nilai bobot kriteria perhitungan AHP, edit dan hapus data nilai kriteria perhitungan AHP. Tampilan halaman kelola nilai bobot kriteria ditunjukkan pada Gambar 7. Halaman hasil perhitungan fuzzy AHP nilai kriteria dan perhitungan fuzzy AHP nilai alternatif ditunjukkan pada Gambar 8.

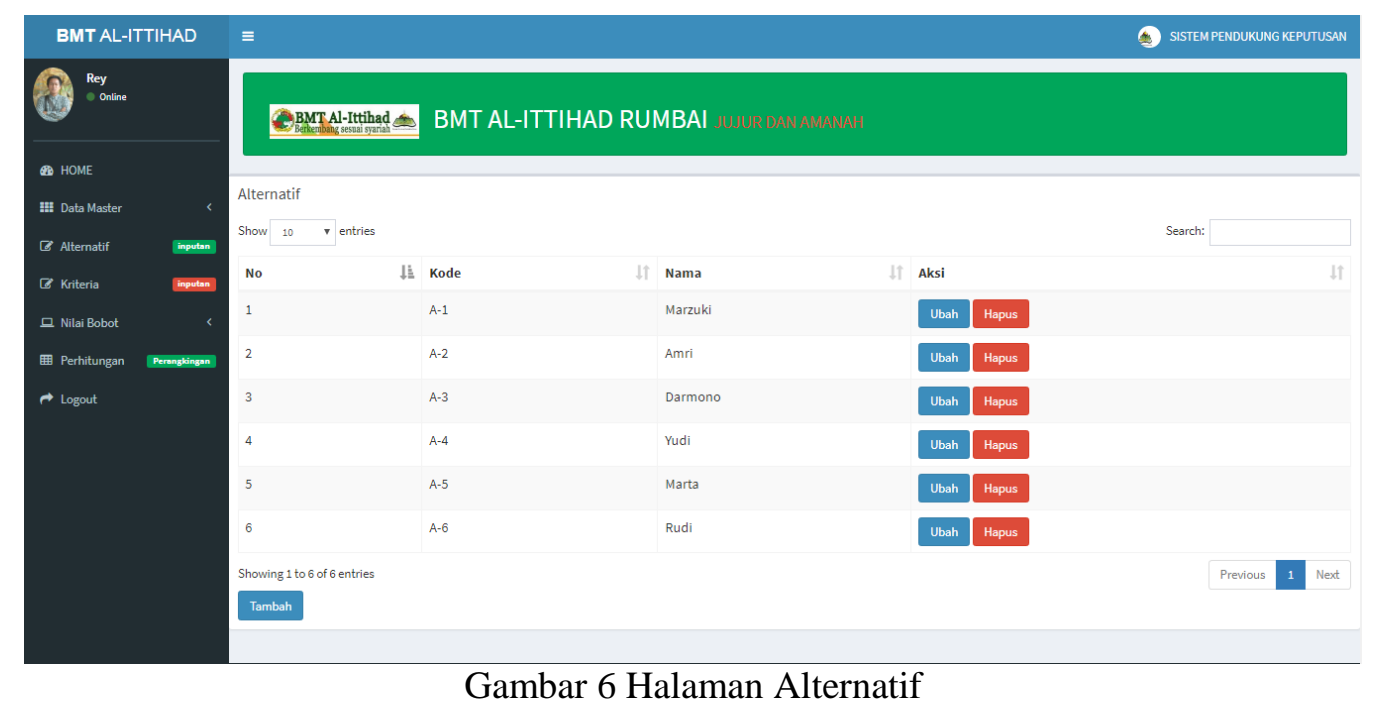




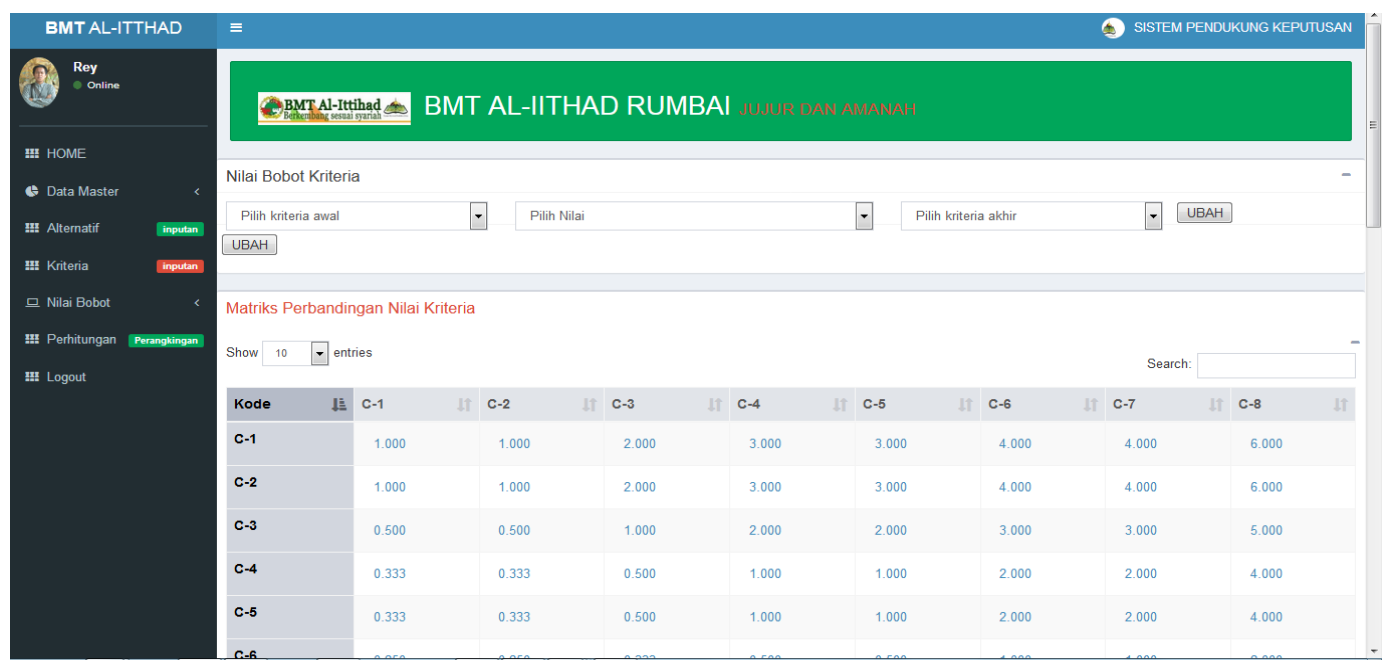

Gambar 7 Halaman Kelola Nilai Bobot Kriteria

Halaman perhitungan merupakan halaman yang diakses oleh account officer. Halaman perhitungan dapat melihat hasil perhitungan fuzzy AHP nilai kriteria dan perhitungan fuzzy AHP nilai alternatif. Tampilan halaman perhitungan dapat dilihat pada gambar 10.

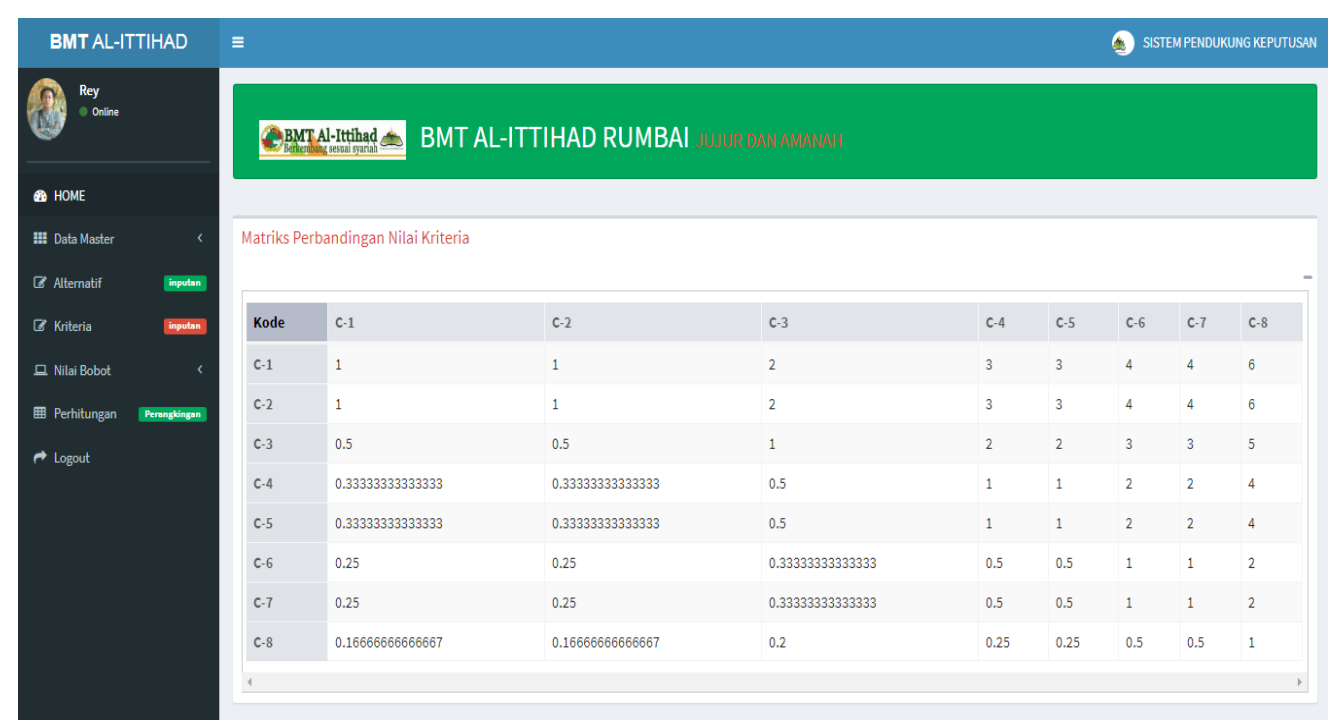

Gambar 8 Halaman Perhitungan

Kepala pembiayaan dan manajer bisa melihat data yang berisikan informasi data-data pembiayaan yang dilakukan oleh anggota BMT Al-ittihad yang ditunjukkan pada Gambar 9. 


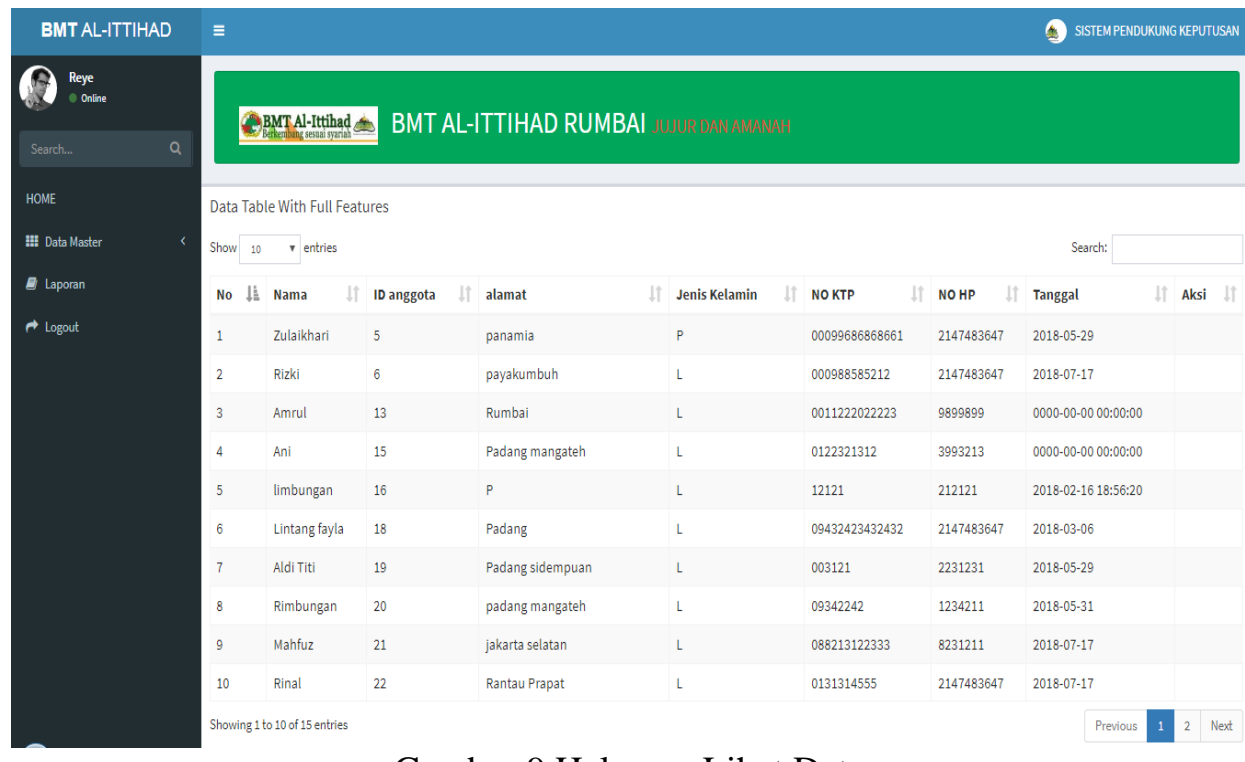

Gambar 9 Halaman Lihat Data

Kepala pembiayaan dapat memberikan rekomendasi untuk anggota pembiayaan yang layak diberikan pembiayaan yang ditunjukkan pada Gambar 10. Selanjutnya Manajer melihat hasil perhitungan berupa perangkingan dan rekomendasi dri kepala pembiayaan untuk anggota mana saja yang layak diberikan pembiayaan yang ditunjukkan pada Gambar 11.

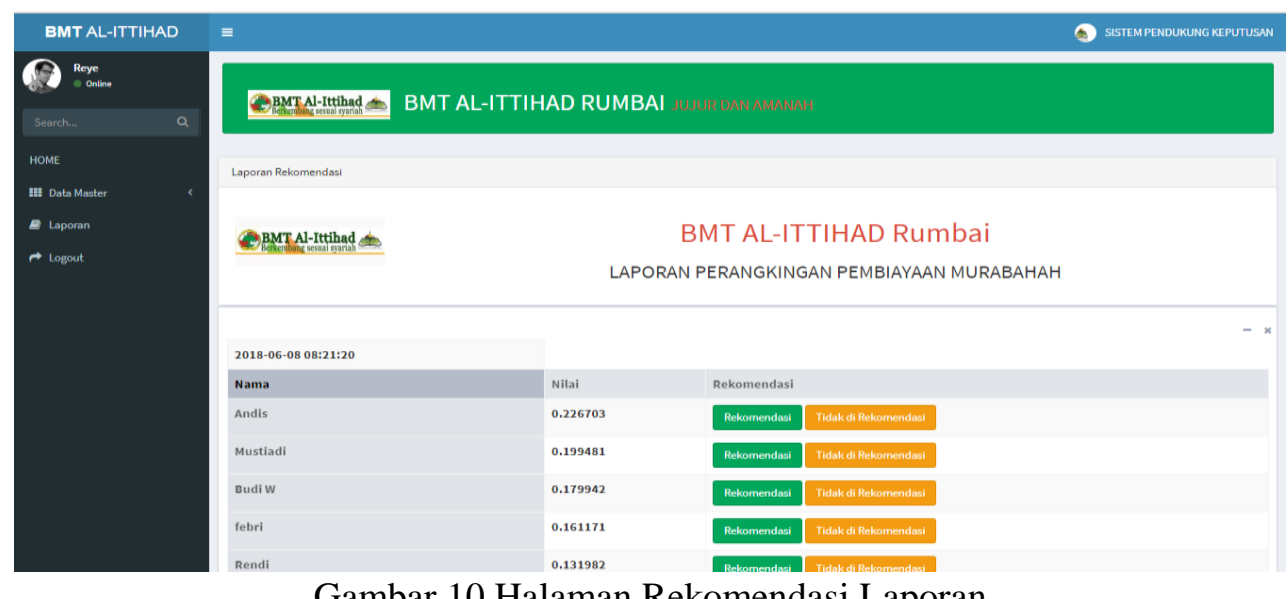

Gambar 10 Halaman Rekomendasi Laporan

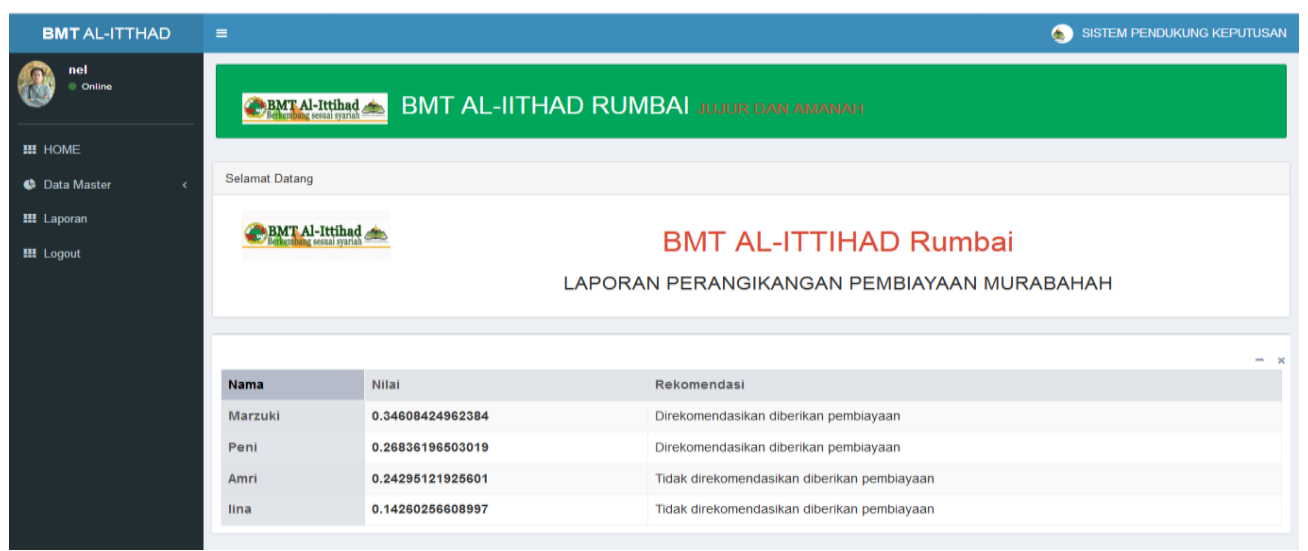

Gambar 11 Halaman Laporan 


\section{KESIMPULAN}

BMT Al-itthad menggunakan kriteria karakter berdasarkan rekomendasi anggota lain,wawancara dan cara berkomunikasi. Penilaian karakter merupakan penilaian yang paling penting berdasarkan hasil wawancara dengan kepala pembiayaan karena penilaian karakter merupakan penilaian untuk melihat apakah anggota sanggup dan amanah membayar hutang. Dikarenakan hal tersebut bersifat subjketif maka dibangun sistem pendukung keputusan pemberian pembiayaan dengan menggunakan metode fuzzy analytic hierarchy process yang mampu memberikan penilaian bersifat objektif. Sistem ini dibangun menggunakan bahasa pemrograman PHP, MySQL, sedangkan metode pengembangan sistem menggunakan V-model dan UML sebagai standar pemodelannya. Sistem pendukung keputusan untuk menentukan anggota yang layak mendapatkan pembiayaan murabahah ini dapat mempercepat dan mempermudah proses penentu anggota yang layak menerima pembiayaan murabahah yang mampu diukur dengan kecepatan yang dihasilkan oleh sistem.

\section{SARAN}

Sistem ini dibangun dinamis, untuk itu peneliti selanjutnya diharapkan dapat mengembangkan aplikasi dengan menambahkan kriteria dan pembobotan yang lain.

\section{DAFTAR PUSTAKA}

[1] Lubis A. Aplikasi murabahah dalam perbankan syariah. 2016;02(2):181-202.

[2] Turban.E., Aronson. J.E, Peng Liang.T. Decision Support Systems and Intelligent Systems. 2005; Edisi 7 Jilid 1, Andi Offset, Yogyakarta.

[3] Keen, P. G. W. Adaptive Design for Decision Support Systems. 1980; Data Base, Vol. 12, No. 1 dan 2

[4] Lestari E. Analisa Sistem Pendukung Keputusan Untuk Proses Kenaikan Jabatan Pada PT . X. 2009;1(3):141-50.

[5] Iswara RA, E Santoso, B Rahayudi. Sistem Pendukung Keputusan Untuk penentuan mustahik ( Penerima Zakat ) Menggunakan Metode Fuzzy AHP ( F-AHP ). 2018;2(3):1306-12.

[6] Suryati, MR Hikmawan, R Gustriansyah. Sistem Pendukung Keputusan Pemberian Beasiswa Di Politeknik Negeri Sriwijaya Menggunakan Metode Fuzzy Logic Tsukamoto. 2018;(July 2016).

[7] Riyandi AO, N Dengen, JI Komputer, U Mulawarman. Sistem Pendukung Keputusan Kelayakan Pemberian Bantuan Dana Atau Kredit Untuk Usaha Kecil Menengah (UKM) Pada Bank Negara Indonesia (BNI). 2017;2(1).

[8] Prasetyo SY. Sistem Pendukung Keputusan Prioritas Pendirian Bts Menggunakan Metode Fuzzy AHP ( Studi Kasus : PT . Indosat Solo ). 1996;21-8.

[9] Shega HNH, R Rahmawati, H Yasin. Penentuan Faktor Prioritas Mahasiswa Dalam Memilih Telepon Seluler Merk Blackberry Dengan Fuzzy AHP. 2012;1:73-82.

[10] Dorothy, Graham, dkk. "Fondation of Software Testing". ISTQB Certification. 2006. 